\title{
Comunicação
}

\section{Common bean grain yield as affected by sulfur fertilization and cultivars}

\author{
Adriano Stephan Nascente ${ }^{1 *}$, Luis Fernando Stone ${ }^{1}$, Leonardo Cunha Melo ${ }^{1}$
}

$10.1590 / 0034-737 X 201764050013$

\begin{abstract}
A better understanding of the differential growth of common bean cultivars with increasing soil sulfur (S) availability can indicate how to improve common bean grain yield in soils of Savannas. The objective of this study was to evaluate the response of sprinkler-irrigated common bean cultivars to sulfur fertilization in a no-tillage system. The experiment was designed as a randomized block in a split-plot scheme with sulfur rates $\left(0,10,20,40\right.$, and $\left.60 \mathrm{~kg} \mathrm{ha}^{-1}\right)$ as main plots and common bean cultivars (BRS Requinte, BRS Cometa, Diamante Negro, BRS Grafite, BRS Valente, and Corrente) as subplots, with three replications. Common bean cultivars did not differ regarding grain yield response to sulfur rates, which fitted to a quadratic equation. Among the cultivars tested, only BRS Requinte and BRS Valente differed in grain yield for $\mathrm{S}$ fertilization, the first being more productive. Moreover, $\mathrm{S}$ fertilization allows significant increases in common bean grain yield in average of six cultivars and must be considered in cropping systems aiming for high yields.
\end{abstract}

Key words: Phaseolus vulgaris L.; sulfated fertilization; savanna soils.

\section{RESUMO}

\section{Produtividade de grãos do feijoeiro comum em função da adubação com enxofre e cultivares}

A melhor compreensão do crescimento diferencial de cultivares de feijoeiro comum com o aumento da disponibilidade de enxofre (S) no solo pode indicar como melhorar a produtividade de grãos do feijoeiro comum em solos do Cerrado. O objetivo deste estudo foi avaliar a resposta de cultivares de feijoeiro comum, sob irrigação, ao enxofre, no sistema plantio direto. $\mathrm{O}$ delineamento experimental foi em blocos casualizados, em esquema de parcelas subdivididas, com doses de enxofre $\left(0,10,20,40\right.$ e $\left.60 \mathrm{~kg} \mathrm{ha}^{-1}\right)$ como parcelas e cultivares de feijoeiro comum (BRS Requinte, BRS Cometa, Diamante Negro, BRS Grafite, BRS Valente e Corrente) como subparcelas, com três repetições. As cultivares de feijoeiro não diferiram quanto à resposta da produtividade de grãos às doses de enxofre, a qual se ajustou a uma equação quadrática. Entre as cultivares testadas, somente a BRS Requinte e a BRS Valente diferiram quanto à produtividade de grãos para a adubação com S, sendo a primeira mais produtiva. A adubação com enxofre proporciona aumentos significativos na produtividade de grãos do feijoeiro comum na média de seis cultivares e deve ser considerada em sistemas de cultivo visando elevadas produtividades.

Palavras-chave: Phaseolus vulgaris L.; adubação sulfatada; solos de cerrado.

\footnotetext{
Submitted on February $23^{r d}, 2016$ and accepted on September 12 $2^{\text {th }}, 2017$.

Embrapa Arroz e Feijão, Santo Antônio de Goiás, Goiás, Brazil. adriano.nascente@embrapa.br; luis.stone@embrapa.br; leonardo.melo@embrapa.br

Corresponding author: adriano.nascente@embrapa.br
}

Rev. Ceres, Viçosa, v. 64, n.5, p. 548-552, set/out, 2017 


\section{INTRODUCTION}

The common bean crop is of significant economic importance in many countries and is considered an important source of protein for human consumption. In the 2012 harvest, 23 million $\mathrm{Mg}$ of common bean grains were produced worldwide and the major producers were Myanmar (3.72 Mg), India (3.63 Mg), Brazil (2.82 Mg), China (1.45 Mg), the USA (1.44 Mg), and Mexico (1.08 Mg) (FAOSTAT, 2015). However, despite its importance, technology is seldom used for common bean crops, resulting in a global average grain yield of only $804 \mathrm{~kg} \mathrm{ha}^{-1}$ (FAOSTAT, 2015). More specifically in Brazil, this crop represented $5.85 \%$ of the entire grain production area and $1.7 \%$ of the total grain production in the 2013/2014 growing season. The common bean crop is the $3^{\text {rd }}$ largest agricultural crop in Brazil and occupies an area of 3.2 million hectares, behind only soybean (Glycine max L. Merrill) and corn (Zea mays L.) (CONAB, 2015). The Brazilian average yield of the common bean in the growing season of 2014/2015 was $1,044 \mathrm{~kg} \mathrm{ha}^{-1}$, but there are farmers reaching grain yields higher than 3,500 $\mathrm{kg} \mathrm{ha}^{-1}$ (CONAB, 2015).

To achieve a higher grain yield, the plant fertilization management must be improved because a properly balanced supply of nutrients and the use of fertilizers can achieve significant increases in grain yield (Fageria et al., 2011). The common bean requires high amounts of sulfur (S) for its development, because of its high content of protein. This nutrient is also involved in the enzymatic processes and redox reactions and is a constituent of the amino acids cystine, cysteine, and methionine, which constitute about $90 \%$ of the plant S (Malavolta et al., 1997).

Sulfur is the third most exported nutrient by common beans and about 5.4 to $6.0 \mathrm{~kg} \mathrm{~S}$ in $1,000 \mathrm{~kg}$ of grain are exported, which represents about $20-25 \%$ of the amount absorbed. In sulfur-deficient plants, there is loss of plant grow strength; they become weak with thin stems and leaves with a pale yellowish green color, leading to a reduction in the formation of branches and the number of flowers and pods, resulting in low grain yield (Cusciol et al., 2006). Sulfur is found in the soil in both organic and inorganic forms. Although the first form represents more than $90 \%$ of total S in most soils (Fageria et al., 2011), it is the inorganic form (sulfate anion $-\mathrm{SO}_{4}^{-2}$ ) that is absorbed by plants. Thus, the soil ability to meet the demand of the plant nutrient is closely related to the content of soil organic matter and the mineralization of organic $\mathrm{S}$ to inorganic forms, such as sulfate. In the soil solution, sulfate is easily leached because it is weakly retained by the coordination mechanism of adsorption (Ishiguro \& Makino, 2011) and the sulfate adsorption is higher in clayey soils rich in iron and aluminum oxides (Jung et al., 2011).
Thus, the most likely responses to sulfated fertilization occur in soil with high $\mathrm{pH}$ and low clay and organic matter contents (Rheinheimer et al., 2007). In addition, the increased use of fertilizers with concentrated formulations without $\mathrm{S}$ or with low content, the reduction in the use of $\mathrm{S}$ as defensive, and the increased extraction and exportation of this nutrient due to the increase in grain yield have made $S$ deficiency more frequent (Furtini Neto et al., 2000). When there is not a sufficient supply of $S$, the application of high rates of other nutrients (N, P, and K) may not result in increased yields (Crusciol et al., 2006).

Rosolem \& Marubayashi (1994) suggested the application of $20 \mathrm{~kg} \mathrm{ha}^{-1} \mathrm{~S}$ when its content in the soil is less than $2.0 \mathrm{mg} \mathrm{kg}^{-1}$, while Rein \& Sousa (2004) recommended the use of $15-30 \mathrm{~kg} \mathrm{ha}^{-1}$ of $\mathrm{S}$, even in soil with average content $\left(5-9 \mathrm{mg} \mathrm{dm}^{-3} \mathrm{~S}\right)$, especially in areas well fertilized with other nutrients.

In common bean crop, Ambrosano et al. (1996) recommended the application of $30 \mathrm{~kg} \mathrm{ha}^{-1}$ of S when aiming at grain yield exceeding $2000 \mathrm{~kg} \mathrm{ha}^{-1}$, regardless of the sulfur content in the soil. Corroborating this recommendation, Osório Filho et al. (2007) found, for common bean in no-till, a maximum estimated yield of 3,130 $\mathrm{kg} \mathrm{ha}^{-1}$ with the application of $25 \mathrm{~kg} \mathrm{ha}^{-1}$. Crusciol et al. (2006), however, also for common bean in no-tillage, required a greater dose, $49 \mathrm{~kg} \mathrm{ha}^{-1} \mathrm{~S}$, to achieve maximum yield of 2,644 $\mathrm{kg} \mathrm{ha}^{-1}$.

These divergent data raise the hypothesis that, maybe, there is a difference among cultivars in the ability of plants to respond to sulfur application. Our hypothesis is that common bean cultivars have different responses to $\mathrm{S}$ fertilization. The objective of this study was to evaluate the response of sprinkler-irrigated common bean cultivars to sulfur fertilization in a no-tillage system.

\section{MATERIAL AND METHODS}

The experiment was conducted on Fazenda Capivara, Embrapa Arroz e Feijão, located in Santo Antônio de Goiás, $\mathrm{GO}$, at $16^{\circ} 29^{\prime} 15^{\prime \prime} \mathrm{S}$ and $49^{\circ} 18^{\prime} 45^{\prime \prime} \mathrm{W}$ and $823 \mathrm{~m}$ of altitude. The climate is tropical savanna and considered Aw according to Köppen's classification. There are two welldefined seasons: dry season, from May to September (autumn/winter), and rainy season, from October to April (spring/summer). The average annual rainfall is $1485 \mathrm{~mm}$ and the average annual temperature is $22.7^{\circ} \mathrm{C}$, ranging annually from $14.2^{\circ} \mathrm{C}$ to $34.8^{\circ} \mathrm{C}$.

The soil is classified as a clayey (kaolinitic and thermic Typic Haplorthox) acidic soil. Initial soil chemical analyses were performed at a depth of $0-0.20 \mathrm{~m}$ to characterize the experimental area and presented $\mathrm{pH}\left(\mathrm{H}_{2} \mathrm{O}\right)=5.7, \mathrm{Ca}^{2+}=$ $18.0 \mathrm{mmol}_{\mathrm{c}} \mathrm{dm}^{-3}, \mathrm{Mg}^{2+}=10.0 \mathrm{mmol}_{\mathrm{c}} \mathrm{dm}^{-3}, \mathrm{Al}^{3+}=0.0 \mathrm{mmol}_{\mathrm{c}}$ $\mathrm{dm}^{-3}, \mathrm{H}^{+}+\mathrm{Al}^{3+}=28.0 \mathrm{mmol}_{\mathrm{c}} \mathrm{dm}^{-3}, \mathrm{P}=17.2 \mathrm{mg} \mathrm{dm}^{-3}, \mathrm{~K}^{+}=83.0$ 
$\mathrm{mg} \mathrm{dm}{ }^{-3}, \mathrm{~S}=5 \mathrm{mg} \mathrm{dm}^{-3}, \mathrm{Cu}^{2+}=2.3 \mathrm{mg} \mathrm{dm}^{-3}, \mathrm{Zn}^{2+}=5.9 \mathrm{mg}$ $\mathrm{dm}^{-3}, \mathrm{Fe}^{3+}=80.7 \mathrm{mg} \mathrm{dm}^{-3}, \mathrm{Mn}^{2+}=16.2 \mathrm{mg} \mathrm{dm}^{-3}$, and soil organic matter $=40.1 \mathrm{~g} \mathrm{~kg}^{-1}$.

The experimental area was sprinkler-irrigated by central pivot and had been cultivated in a no-tillage system for five consecutive years. The last crop was soybean. Fifteen days before common bean sowing, glyphosate (1.6 $\mathrm{kg} \mathrm{ha}^{-1}$ of acid equivalent) was applied.

The field experiment was arranged as a randomized block design in a split-plot scheme with three replications, having $\mathrm{S}$ rates $\left(0,10,20,40\right.$, and $\left.60 \mathrm{~kg} \mathrm{ha}^{-1}\right)$ with source ammonium sulphate ( $20 \%$ of $\mathrm{N}$ and $24 \%$ of $\mathrm{S}$ ) in the main plots, and common beans cultivars (BRS Requinte, BRS Cometa, Diamante Negro, BRS Grafite, BRS Valente, and Corrente) in the subplots. The first two cultivars had grain type 'carioca' (grains with beige background with dark brown stripes), the following three had black grains, and
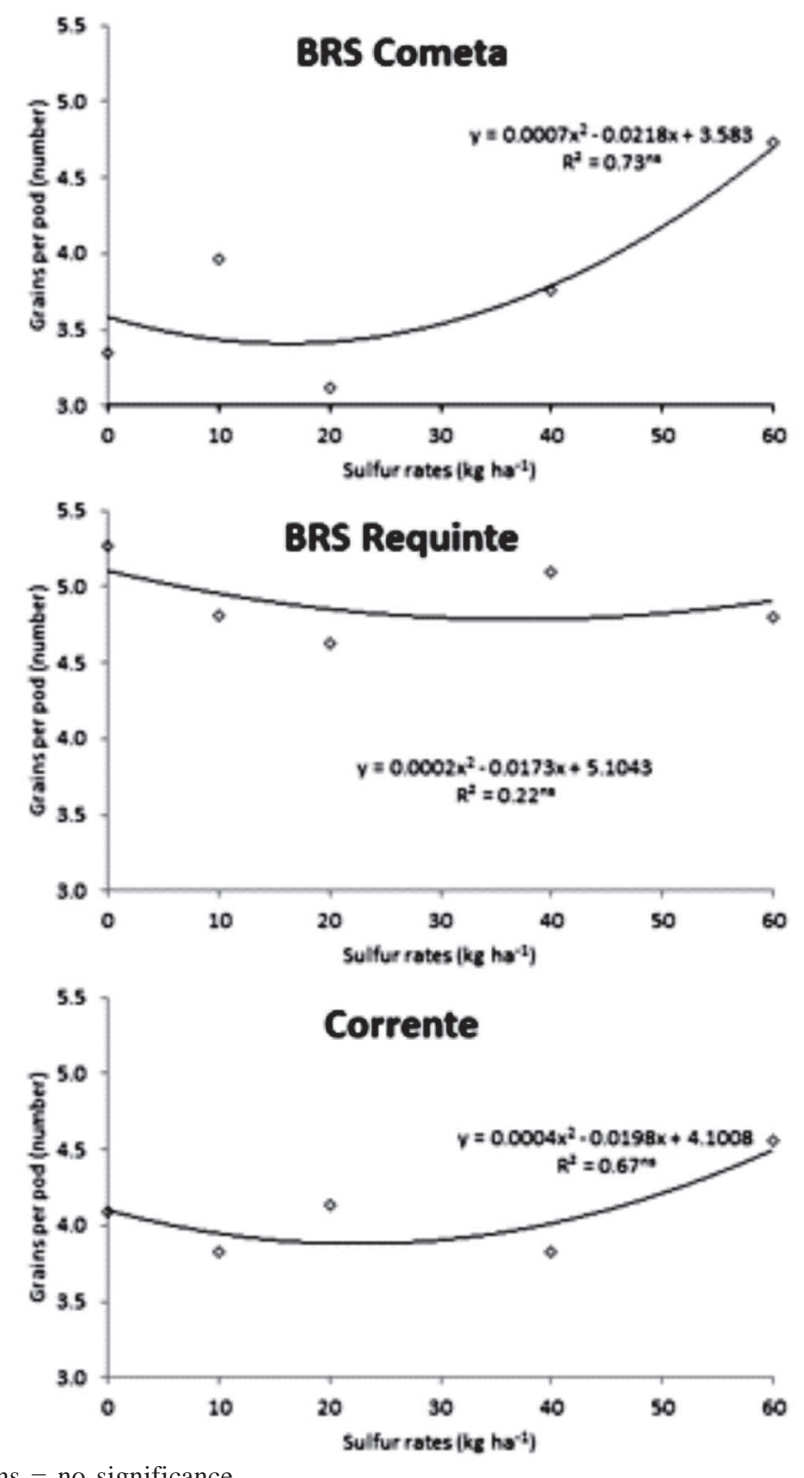

the last one had grain type 'mulatinho' (grains with beige background without stripes). Each subplot consisted of four 5-m long lines and the two central lines without $1 \mathrm{~m}$ at both ends were considered as useful area.

The sowing of the common bean cultivars was performed by hand on June $16^{\text {th }}, 2014$ in a $0.40 \mathrm{~m}$ row spacing and with 10 seeds per meter. Sowing fertilization was done with $60 \mathrm{~kg}$ of $\mathrm{N} \mathrm{ha}^{-1}$ as urea, $100 \mathrm{~kg}$ of $\mathrm{P}_{2} \mathrm{O}_{5} \mathrm{ha}^{-1}$ as triple superphosphate, and $100 \mathrm{~kg}_{\text {of }} \mathrm{K}_{2} \mathrm{O} \mathrm{ha}^{-1}$ as potassium chloride. At that time, we also broadcast the sulfur rates on the soil accordingly to each treatment. Seedling emergence occurred at eight days after sowing. In the $\mathrm{V}_{4}$ vegetative stage of the common bean (three trifoliate leaves), a topdressing fertilization of $60 \mathrm{~kg}$ of $\mathrm{N} \mathrm{ha}^{-1}$ as urea was performed for all plots. When the $\mathrm{N}$ dose was supplied as urea we deducted the $\mathrm{N}$ dose already applied as ammonium sulfate in the $\mathrm{S}$ fertilization. Other cultural
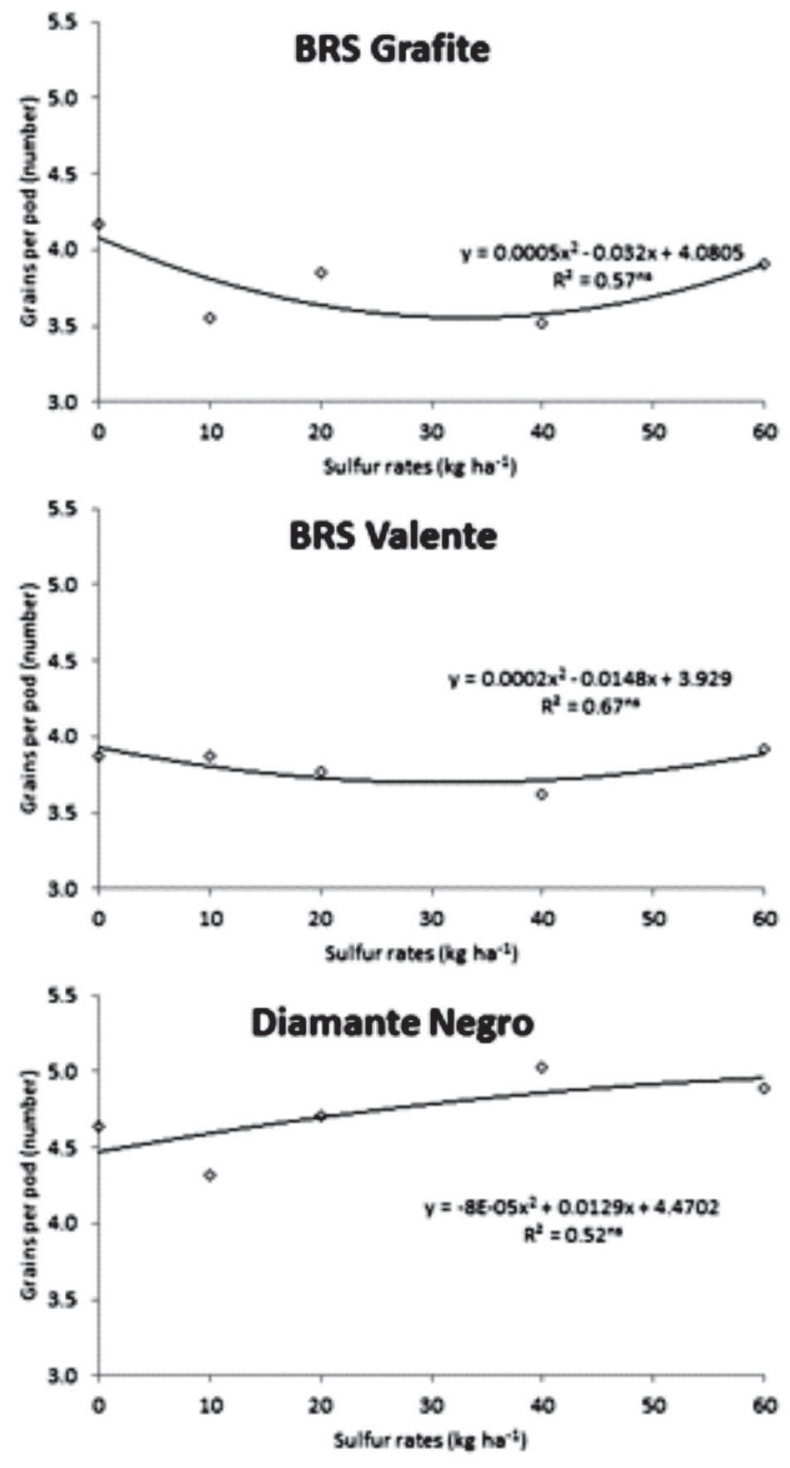

Figure 1: Number of grains per pod of common bean cultivars as a function of sulfur rates.

Rev. Ceres, Viçosa, v. 64, n.5, p. 548-552, set/out, 2017 
practices were performed according to the recommendations for the crop to keep the area free of weeds, disease, and pests.

The usable area of the plots was harvested by hand and was followed by mechanized thresher. The harvested common bean grains were weighed and the yield expressed as $130 \mathrm{~g} \mathrm{~kg}^{-1}$ of humidity. In addition, the following common bean characteristics were assessed: number of pods per plant and number of grains per pod (evaluated in 10 plants per plot that were chosen at random).

Data were subjected to an analysis of variance and the means were compared by Tukey's test at $p<0.05$. If the quantitative data (sulfur rates) were significant, then the regression analysis was conducted. These analyses used the SAS statistical software. We also made the Pearson's correlation between yield and yield components considering sulfur rates.

\section{RESULTS AND DISCUSSION}

The interaction between the sulfur rates and cultivars was significant only for the number of grains per pod (Figure 1). The number of pods per plant was not affected either by the sulfur rates or by cultivars (Table 1) and the grain yield was significantly affected by single effect of these two factors (Table 1 and Figure 2).

The number of grains per pod is a characteristic of high genetic heritability, with little influence of the environment (Crusciol et al., 2006). However, we could see that there are differences among cultivars regarding sulfur rates and this fertilization caused significant differences in this characteristic. Cultivars BRS Requinte and Diamante Negro had the highest values of number of grains per pod and differed from the other cultivars (Table 1).
In the response of grain yield to cultivars, we could see that BRS Requinte had the highest grain yield and differed from the BRS Valente (Table 1). The response to sulfated fertilization was quadratic, with estimated maximum grain yield of $3,338 \mathrm{~kg} \mathrm{ha}^{-1}$ in the rate of $27.8 \mathrm{~kg} \mathrm{ha}^{-1}$ (Figure 2). This value is close to that obtained by Osório Filho et al. (2007) for common bean in no-till system and agrees with the recommendation of Ambrosano et al. (1996). This result of grain yield was probably due to the effect of sulfur rates in the number of pods per plant. The $S$ deficiency causes a reduction in the formation of branches and in the number of flowers and pods, and consequently on common bean yield (Fageria et al., 2011).

Considering the means in each dose of sulfur, the number of pods per plant was positively correlated with grain yield $(r=0.82 ; \mathrm{p}<0.05)$ and negatively with the number of grains per pod $(r=-0.94 ; p<0.05)$ (Table 2). Negative correlations between the primary components of grain yield occur in most crops, particularly under conditions of environmental stress, which cannot allow maximum expression of the genes that control these components. It is believed that these correlations are due to the action of the environment on genetically independent components, which develop in a sequential manner, that is, first there is the number of pods per plant, then the number of grains per pod, and finally the mass of grains (Fageria et al., 2011). Productivity also showed a negative correlation with the number of grains per pod $(\mathrm{r}=$ $-0.90 ; \mathrm{p}<0.05$ ) (Table 2).

Our results showed that $\mathrm{S}$ fertilization was important to increase the grain yield of common beans. If farmers had made the fertilization without $\mathrm{S}$, they would have reach only $2,797 \mathrm{~kg} \mathrm{ha}^{-1}$, according to the equation of Figure 2.

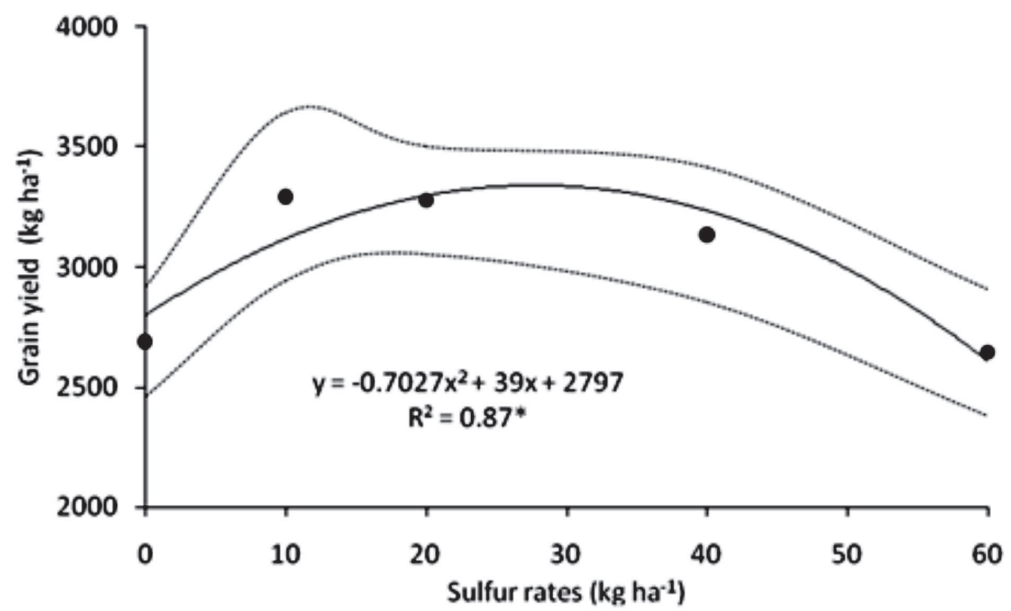

Dots represent means of grain yield of six cultivars in each sulfur rates.

Dashed lines represent confidence interval.

* Significant at $\mathrm{p}<0.05$.

Figure 2: Common bean grain yield as a function of sulfur rates. 
Table 1: Number of pods per plant (NPP), number of grains per pod (NGP), and grain yield (YIELD) of common bean as a function of cultivars

\begin{tabular}{lccc}
\hline Cultivar & NPP $($ no. $)$ & NGP $($ no. $)$ & YIELD $\left(\mathbf{k g ~ h a} \mathbf{~}^{-1}\right)$ \\
\hline BRS Cometa & $17.25 \mathrm{a}$ & $3.79 \mathrm{~b}$ & $2,945 \mathrm{ab}$ \\
BRS Grafite & $15.39 \mathrm{a}$ & $3.80 \mathrm{~b}$ & $2,914 \mathrm{ab}$ \\
BRS Requinte & $18.40 \mathrm{a}$ & $4.92 \mathrm{a}$ & $3,389 \mathrm{a}$ \\
BRS Valente & $19.22 \mathrm{a}$ & $3.81 \mathrm{~b}$ & $2,636 \mathrm{~b}$ \\
Corrente & $16.89 \mathrm{a}$ & $4.10 \mathrm{~b}$ & $3,060 \mathrm{ab}$ \\
Diamante Negro & $17.59 \mathrm{a}$ & $4.71 \mathrm{a}$ & $3,114 \mathrm{ab}$ \\
Coefficient of Variation $(\%)$ & 20.74 & 9.96 & 18.88 \\
\hline
\end{tabular}

${ }^{1}$ Means followed by the same letter in column do not differ by Tukey's test at $\mathrm{p}<0.05$.

Table 2: Pearson's correlation among number of pods per plant (NPP), number of grains per pod (NGP), and grain yield (YIELD) of common bean considering the means in each dose of sulfur

\begin{tabular}{lccc}
\hline & NPP & NGP & YIELD \\
\hline NPP & 1 & & \\
NGP & $-0,94 *$ & 1 & 1 \\
YIELD & $0,82 *$ & $-0,90 *$ & 1 \\
\hline
\end{tabular}

*Significant at $5 \%$ of probability.

On the other hand, if they put around $30 \mathrm{~kg} \mathrm{ha}^{-1}$ of $\mathrm{S}$, the grain yield would increase to $3,338 \mathrm{~kg} \mathrm{ha}^{-1}$. Therefore, this nutrient has importance in the yield of common beans and should be included in recommendations of common bean fertilization. Typically, in common bean cultivation, farmers apply lime and fertilizers such as $\mathrm{N}, \mathrm{P}$, and $\mathrm{K}$, but $\mathrm{S}$ is seldom applied (Bona \& Monteiro, 2010), which also may limit the crop yield.

\section{CONCLUSIONS}

Common bean cultivars do not differ regarding grain yield response to sulfur rates, which fit a quadratic equation.

Among the cultivars tested, only BRS Requinte and BRS Valente differ in grain yield for $\mathrm{S}$ fertilization, the first being more productive.

Sulfur fertilization allows significant increases in common bean grain yield in the average of six cultivars and must be considered in cropping systems aiming at high yields.

\section{REFERENCES}

Ambrosano EJ, Tanaka RT, Mascarenhas HAA, Raij BV, Quaggio JA \& Cantarella H (1996) Leguminosas e oleaginosas. In: Raij BV, Cantarella H, Quaggio JA \& Furlani AMC (Eds.) Recomendações de adubação e calagem para o Estado de São Paulo. $2^{\mathrm{a}}$ ed. Campinas, IAC. p.189-203. (Boletim técnico, 100).

Bona FD \& Monteiro FA (2010) Marandu palisadegrass growth under nitrogen and sulphur for replacing signal grass in degraded tropical pasture. Scientia Agricola, 67:570-578.

CONAB (2015) Acompanhamento da safra brasileira: Grãos. Disponível em: <http://www.conab.gov.br/OlalaCMS/uploads/arquivos/15_01_09_09_00_21_boletim_graos_janeiro_2015.pdf >. Acessado em: 08 de fevereiro de 2016.
Crusciol CAC, Soratto RP, Silva LM \& Lemos LB (2006) Aplicação de enxofre em cobertura no feijoeiro em sistema de plantio direto. Bragantia, 65:459-465.

Fageria NK, Baligar VC \& Jones CA (2011) Growth and mineral nutrition of field crops. $3^{\text {a }}$ ed. Boca Raton, CRC Press. 586 p.

FAOSTAT (2015) Production: Crops. Disponível em: <www.faostat.fao.org>. Accessed on: September 29 2015.

Furtini Neto AE, Fernandes LA, Faquin V, Silva IR \& Accioly AMA (2000) Resposta de cultivares de feijoeiro ao enxofre. Pesquisa Agropecuária Brasileira, 35:567-573.

Ishiguro M \& Makino T (2011) Sulfate adsorption on a volcanic ash soil (allophanic Andisol) under low pH conditions. Colloids and Surfaces A: Physicochemical and Engineering Aspects, 384:121-125.

Jung K, Ok YS \& Chang SX (2011) Sulfate adsorption properties of acid-sensitive soils in the Athabasca oil sands region in Alberta, Canada. Chemosphere, 84:457-463.

Malavolta E, Vitti GC \& Oliveira AS (1997) Avaliação do estado nutricional de plantas: princípios e aplicações. $2^{\mathrm{a}}$ ed. Piracicaba, Potafos. 319p.

Osório Filho BD, Rheinheimer DS, Silva LS, Kaminski J \& Dias GF (2007) Deposição do enxofre atmosférico no solo pelas precipitações pluviais e respostas de culturas à adubação sulfatada em sistema plantio direto. Ciência Rural, 37:712-719.

Rein TA \& Sousa DMG (2004) Adubação com enxofre. In: Sousa DMG \& Lobato E (Eds.) Cerrado: correção do solo e adubação. $2^{a}$ ed. Brasília, Embrapa Informação Tecnológica. p.227-244.

Rheinheimer DS, Rasche JWA, Osorio Filho BD \& Silva LS (2007) Resposta à aplicação e recuperação de enxofre em cultivos de casa de vegetação em solos com diferentes teores de argila e matéria orgânica. Ciência Rural, 37:363-371.

Rosolem CA \& Marubayashi OM (1994) Seja o doutor do seu feijoeiro. Informações Agronômicas, 68:01-16. 